\title{
Tanggapan Etika Kristen terhadap Terorisme
}

\author{
Agustina Pasang \\ Sekolah Tinggi Teologi Excelsius Surabaya, Jawa Timur \\ thina340@gmail.com
}

\begin{abstract}
The problems that occur in various cities in Indonesia are not only caused by public dissatisfaction with the economic, political, social, cultural and so on, because often the problems spread to most sensitive problems to SARA (ethnic, religious, racial and intergroup). If the problems arise only because of economic problems it certainly will not have an impact on the burning of churches or acts of anarchist actions that discredit certain ethnic or religious groups that lead to crime of terror or terrorism. The article is a literature review using reference books that contain a discussion about terror and terrorism in the Christian ethical perspective by applying descriptive methods. The conclusion is that the church and believers need to be aware of and increase their social sensitivity and concern about the problems that surround them that it is part of the Christian faith.
\end{abstract}

Keywords: terror; terrorism; ethical response

\begin{abstract}
Abstrak: Persoalan-persoalan yang terjadi di berbagai kota di Indonesia ternyata bukan saja disebabkan oleh ketidakpuasan masyarakat terhadap soal ekonomi, sosial, politik, budaya dan sebagainya, karena seringkali persoalan itu justru merembet ke masalah yang paling sensitif yakni SARA (Suku, Agama, Ras dan Antar Golongan). Artikel ini merupakan kajian literatur atau kajian pustaka dengan menggunakan buku-buku referensi yang memuat bahasan mengenai teror, teroris dan terorisme dalam pandangan etika Kristen dengan menerapkan metode deskriptif. Kesimpulannya, Gereja dan orang percaya perlu menyadari dan meningkatkan kepekaan dan kepedulian sosialnya akan masalah-masalah yang ada di sekitarnya, bahwa masalah adalah bagian dari iman Kristen. Itu sebabnya gereja perlu mengadakan seminar yang membahas teror, teroris dan terorisme secara utuh sehingga jemaat memiliki pemahaman yang benar mengenai hal ini. Demikian halnya dalam khotbah dan pembinaan jemaat mau tidak mau menyinggung masalahmasalah teroris secara terbuka. Di samping itu perlu bersikap bijaksana dalam menyikapi masalah terorisme.
\end{abstract}

Kata kunci: teror, teroris, tanggapan etika Kristen

$$
\text { Article Genesis : }
$$$$
\text { Received: } 04 \text { December } 2019
$$

Revised: 12 December 2019

Accepted: 31 December 2019

\section{PENDAHULUAN}

Pasca peledakan bom World Trade Center di New York Amerika Serikat tanggal 26 Pebruari 1993 hingga tragedi hancurnya gedung kembar tersebut tanggal 11 September 2001, istilah teroris menjadi sangat populer dan peristiwa ini pun diikuti dengan berbagai aksi kekersan lainnya baik peledakan bom mobil, bom bunuh diri dan lain sebagainya. Seiring dengan perkembangan teknologi yang semakin pesat, praktek kejahatan atau kekerasan makin bertambah oleh karena kelompok teroris dengan mudah memiliki berbagai macam senjata dan bahan peledak berkekuatan tinggi yang dapat diandalkan dan dipilih sebagai senjata penghancur massal seperti halnya bom mobil yang digunakan dalam 
peledakan WTC Bombay, Whitehall (Inggris), JW Marriott Hotel dan Kedutaan Besar Australia di Jakarta serta wilayah Timur tengah, adalah termasuk jenis peledak yang mematikan. ${ }^{1}$

Persoalan-persoalan yang terjadi di berbagai kota di Indonesia ternyata bukan saja disebabkan oleh ketidakpuasan masyarakat terhadap soal ekonomi, sosial, politik, budaya dan sebagainya, karena seringkali persoalan itu justru merembet ke masalah yang paling sensitif yakni Suku, Agama, Ras dan Antar Golongan (SARA). Jika persoalan timbul hanya karena masalah ekonomi, tentunya tidak akan berdampak pada pembakaran gereja atau tindakan-tindakan anarkis yang mendeskreditkan suku atau agama tertentu yang bermuara pada kejahatan teror atau terosisme. Mencermati beberapa peristiwa yang terjadi di berbagai kota di Indonesia dapat dimengerti bahwa peristiwa itu pada akhirnya selalu dihubungkan dengan masalah SARA, secara khusus agama. Huru-hara atau keributan di beberapa kota bukan saja menghancurkan dan membakar tempat-tempat ibadah, tetapi juga mendatangkan korban jiwa dan pengungsian penduduk secara massal. Tentang hal ini, Herlianto menegaskan bahwa huru-hara perkotaan yang merusak persatuan bangsa dan agama itu benar-benar mengejutkan, bukan hanya menimbulkan korban jiwa, korban materi yang banyak dan menghambat ekonomi penduduk tetapi juga mempermalukan bangsa Indonesia sebagai negara kesatuan di forum internasional. ${ }^{2}$ Sehubungan dengan hal ini, penulis akan memaparkan mengenai Sikap Etis atau Tanggapan Etika Kristen terhadap Terorisme.

\section{METODE PENELITIAN}

Penelitian ini merupakan kajian literatur atau kajian pustaka dengan menggunakan bukubuku referensi yang memuat bahasan mengenai teror, teroris dan terorisme dalam pandangan etika kristen dengan menerapkan metode deskriptif.

\section{Terorisme}

Istilah teror menurut Kamus Besar Bahasa Indonesia (KBBI) adalah perbuatan (pemerintahan dsb) yang sewenang-wenang (kejam, bengis, dsb), dapat juga berarti usaha menciptakan ketakutan, kengerian dan kekejaman oleh seseorang atau golongan. ${ }^{3}$ Sementara itu Webster New World Dictionary mengartikan bahwa teror merupakan suatu perasaan rasa takut yang luar biasa, atau sesuatu yang mengakibatkan suatu ketakutan dan ketakutan yang memiliki suatu bobot/potensi ketakutan yang mendalam. ${ }^{4}$ Ini menunjukkan bahwa teror adalah sesuatu yang sangat menakutkan, bukan ketakutan yang biasa.

Lebih jauh mengenai definisi teror, Makmur Halim dalam bukunya "Terror, Terroris dan Terrorisme" menjelaskan bahwa kata teror dalam Perjanjian Lama (PL) muncul dalam berbagai ayat salah satunya dalam Mazmur 91:3-5, ditulis dengan kata pah yang berarti jerat dan kata pahad yang berarti to be affraid, fear, terror, dread atau awe. Istilah terror ini

\footnotetext{
${ }^{1}$ Adjie S, Terorisme, (Jakarta: Pustaka Sinar Harapan, 2005), vx

${ }^{2}$ Herlianto, Gereja di Tengah Gejolak Kota-kota, (Bandung: YABINA, 1997), 75.

${ }^{3}$ Departemen Pendidikan dan Kebudayaan, Kamus Besar Bahasa Indonesia (Jakarta: Balai Pustaka, 1988), 939.

${ }^{4}$ Makmur Halim, Terror, Terroris dan Terrorisme, Suatu Perspektif Kristen, (James Steven: Shalom Publishers, tt), 33 .
} 
sangat mengenaskan karena menggambarkan seseorang yang harus mengalami sesuatu yang tidak pernah ia sangka dan alami sebelumnya, jadi pengertian terror atau pahad ini bukanlah takut yang dibuat-buat tetapi rasa takut, kecemasan, kekuatiran yang berasal dari suatu peristiwa, berita, kabar buruk (berupa) ancaman yang membuat seseorang kehilangan rasa aman dan rasa bahagia. ${ }^{5}$ Dalam konsep PL, pahad juga memberikan makna lain yakni rasa takut karena adanya kehadiran Allah yang Mahakudus di tengah-tengah bangsa lain (2 Tawarikh 14:14). Istilah terror atau pahad dalam konsep PL mengandung unsur yang negatif karena rasa takut dan kecemasan bukan karena takut kepada Allah tapi takut kepada satu objek atau ancaman yang membuat seseorang kehilangan keamanan, menimbulkan akibat, dampak, pengaruh yang sangat negatif dalam diri seseorang. ${ }^{6}$

Dalam konsep Perjanjian Baru (PB), kata teror dalam bahasa Yunani phobos artinya takut (fear) atau teror yakni sesuatu yang ditakuti, yang memberikan inspirasi takut, atau takut yang berasal dari objek yang mengakibatkan rasa takut yang negatif (Matius 14:26). Phobos juga memberikan arti rasa takut yang positif yakni kagum, hormat, perasaan yang mendalam dan tanggung jawab terhadap Allah (Lukas 1:12; Roma 3:18). ${ }^{7}$ Dari pengertian di atas jelas bahwa teror baik baik dalam konsep PL manpun PL memiliki pengertian yang sama karena keduanya memberikan arti bahwa teror mengandung rasa takut yang negatif karena ancaman dan takut positif karena kekudusan, kebesaran Allah.

Selanjutnya dari istilah teror ini berkembang kepada istilah teroris (pelaku dari teror) dan terorisme (bicara tentang faham). Kamus Besar Bahasa Indonesia memberikan arti teroris adalah orang yang menggunakan kekerasan untuk menimbulkan rasa takut, biasanya untuk tujuan politik. ${ }^{8}$ Sementara terorisme adalah penggunaan kekerasan untuk menimbulkan ketakutan dalam usaha mencapai suatu tujuan (terutama tujuan politik); praktik-praktik tindakan teror. ${ }^{9}$ Senada dengan pengertian ini, Peter dan Yenny Salim menambahkan bahwa terorisme adalah penggunaan kekerasan atau ancaman untuk menurunkan semangat, menakut-nakuti dan menaklukkan, terutama untuk tujuan politik. ${ }^{10}$ Dengan demikian jelas bahwa terorisme adalah tindakan kekerasan atau ancaman yang dilakukan oleh sekelompok orang atau golongan tertentu untuk mencapai suatu tujuan tertentu, terutama yang berhubungan dengan masalah politik. Terorisme bicara tentang faham dari teroris yang begitu kuat dan memiliki hubungan dengan berbagai prinsip budaya dan latar belakang seorang teroris baik secara individu maupun kelompok. ${ }^{11}$ Sehingga jelas teroris tidak bekerja sendiri melainkan memiliki jaringan yang luas untuk bekerja sama dalam menjalankan aksi mereka, sesuai dengan faham yang mereka miliki.

Teroris bukanlah sesuatu yang baru karena sudah menjadi fenomena yang berkembang, dalam dunia modern sekarang ini teroris bergerak sekaligus melakukan aksi pembu-

\footnotetext{
${ }^{5}$ Ibid., 23-24.

${ }^{6}$ Ibid., 24, 26

${ }^{7}$ Ibid., 31, 32 .

${ }^{8}$ Departemen P\&K, Kamus Besar Bahasa Indonesia, 939.

${ }^{9}$ Ibid.

${ }^{10}$ Peter \& Yenny Salim, Kamus Bahasa Indonesia Kontemporer, (Jakarta: Modern English Press, 1991), 1605.

${ }^{11}$ Halim, Terror, Terroris dan Terrorisme, Suatu Perspektif Kristen, 33.
} 
nuhan dan peledakan bom dan dalam sekejab mempersiapkan diri sendiri atau kelompoknya menjadi mesin pembunuh yang potensial, dapat meluluhlantakkan gedung sekaligus merenggut puluhan bahkan ratusan dan ribuan nyawa orang-orang yang tak bersalah dalam hitungan detik, mengancam stabilitas politik dan ekonomi seluruh bangsa di dunia. Hal ini sangat menakutkan namun inilah kenyataan yang dapat terjadi kapan saja, di mana saja dan pada siapa saja. Secara umum ada tiga kelompok teroris yang beroperasi di seluruh dunia hingga saat ini, yaitu:

\section{Nonstate-supported Group}

Ini adalah kelompok kecil yang memiliki kepentingan khusus, seperti kelompok yang anti aborsi, anti korupsi dan lain sebagainya. Dalam aksinya mereka mem-blow-up permasalahan tersebut dengan melakukan pembakaran, penyanderaan atau aksi lain yang membahayakan individu atau kepentingan umum. Kelompok ini memiliki kemampuan terbatas, tidak memiliki kontak atau dukungan dari pihak luar namun kelompok ini sangat mungkin untuk bergabung dengan kelompok lain. ${ }^{12}$

\section{State-sponsored Groups}

Kelompok ini memperoleh pelatihan, senjata, keperluan logistik, dukungan administrasi dari negara asing seperti Libya, Syria, Iran dan Cuba. Menurut pengamatan Amerika Serikat kelompok teroris dengan kategori ini dinyatakan bertanggung jawab terhadap $70 \%$ insiden internasional teroris yang ditargetkan kepada warga negara/kepentingan Amerika Serikat diseluruh dunia. Dukungan diterima dari negara sponsor, dipersiapkan dengan kemampuan khusus termasuk perjalanan secara internasional, mendapat senjata yang canggih, alat peledak serta koordinat aktivitas dengan kelompok lain. ${ }^{13}$

\section{State-directed Groups}

Ini adalah suatu negara yang mengorganisasi dukungan kepada kelompok teroris secara langsung seperti negara Iran yang memutuskan untuk mengembangkan sekitar 2.500 personel satuan special forces pada tahun 1984 yang akan digunakan sebagai a primary tactics dalam rangka penyebaran paham Islam fundamentalis lewat wilayah Teluk Persia dan Afrika Utara, pasukan ini terdiri dari individu-individu yang siap melakukan misi bunuh diri jika komando menghendakinya. State-directed-terrorist beroperasi di negara-negara Blok Timur dan lainnya, sebagai contoh Korea Utara menggunakan sebuah tim Statedirected dalam pembunuhan tahun 1983 terhadap beberapa pejabat Korea Selatan yang berkunjung ke Rangoon, State-directed terrorist dari Nikaragua menyerang dan memukul Kardinal Katolik yang dipaksa keluar dari kota tersebut dan sebelumnya telah memberikan peringatan untuk berhenti bicara kepada pemerintahan Sandinista. ${ }^{14}$

Dari penjelasan ini dapat dimengerti bahwa kelompok teroris memiliki jaringan dengan yang bukan hanya sesama kelompok teroris tapi juga dengan negara-negara tertentu yang menunjukkan bahwa dengan meningkatnya State-sponsored dan State-directed group,

\footnotetext{
${ }^{12}$ Adjie S, Terorisme, 16.

${ }^{13}$ Ibid., 16-17.

${ }^{14}$ Ibid., 17-18.
} 
maka secara signifikan telah mengangkat keberadaan kelompok teroris dengan segala ancamannya yang menakutkan dunia ditunjang keberadaan mereka yang memiliki kapabilitas dengan persenjataan canggih dan dukungan dari berbagai pihak.

\section{Organisasi Kelompok Teroris}

Sebagaimana halnya dengan organisasi-organisasi pada umumnya, maka kelompok teroris pun memiliki organisasi di mana dalam gerakannya teroris harus memiliki pemimpin yang efektif dan struktur yang baik untuk dapat bertahan lama. Dalam kelompok teroris, seorang pemimpin memiliki dedikasi secara profesional, orang yang jenius, karismatik dan sering berlatar belakang keluarga mampu (kaya) atau individu yang memiliki penghasilan di atas rata-rata. Para pemimpin tidak berhubungan langsung dalam menentukan siasat operasi, lebih suka menggunakan aksi dari belakang layar sambil memerintahkan anggota tim lain untuk memasang bom, melakukan pembunuhan atau mengambil bagian dalam penyerangan. ${ }^{15}$ Hal ini menunjukkan bahwa seorang pemimpin dalam kelompok teroris bukanlah orang biasa melainkan seorang yang memiliki pengaruh. Di samping pemimpin, anggota kelompok terorispun ikut berperan aktif dalam kelompoknya dengan memberikan dukungan baik berupa materiil maupun finansial.

Dalam organisasi teroris ada yang disebut pendukung aktif, terdiri dari anggota kelompok teroris itu sendiri maupun dari luar organisasi yang berusaha untuk mengumpulkan dana untuk pembiayaan kelompok teroris dan biasanya dana tersebut diperoleh dari masyarakat yang diperoleh secara ilegal. Sementara itu pendukung pasif adalah masyarakat yang memberikan dukungan kepada organisasi teroris tetapi tidak melibatkan diri secara langsung dalam aktivitas kriminal mereka, pendukung ini memberikan bantuan berupa dana, kendaraan dan lain sebagainya. ${ }^{16}$ Meskipun memiliki jaringan yang intelijen dan pendukung yang kuat namun untuk alasan keamanan jumlah personel dari unit tactics (militer) di lapangan dibatasi. Anggota dari unit tactics adalah orang yang meledakkan bom, melakukan pembunuhan, melaksanakan penculikan, pembajakan, penyanderaan dan aksi spektakuler lain dalam kelompok teroris. ${ }^{17}$

Keseluruhan anggota teroris adalah orang yang berdedikasi tinggi terhadap kelompoknya, nampak dalam aksi bom bunuh diri yang dilakukan sesuai dengan petunjuk pemimpin. Peristiwa ini pun bukan lagi sesuatu yang baru di Indonesia karena dalam beberapa peristiwa pemboman yang terjadi dilakukan dalam aksi bom bunuh diri seperti di Bali beberapa waktu yang lalu. Peristiwa ini menunjukkan bahwa organisasi dalam kelompok teroris bukanlah organisasi biasa melainkan organisasi yang kuat karena memiliki jaringan yang kuat dan pendukung yang banyak baik dari dalam negeri maupun luar negeri. Jika dicermati aksi teroris yang terjadi pun mengalami perubahan seiring dengan perkembangan zaman, beberapa negara di dunia menyatakan diri perang melawan terorisme namun teroris tetap bertahan hidup dengan ancaman yang semakin menakutkan, Stott menyatakan “...over the last ten years the growth of terrorism has reached epic proportions, many countries

\footnotetext{
${ }^{15}$ Ibid., 19.

${ }^{16}$ Ibid., 21-22.

${ }^{17}$ Ibid., 23.
} 
including the USA, Kenya, Spain, Peru, Indonesia, Israel, Palestine, Northern Ireland and Britain have seen Horrific violence perpetrated by terrorists from one background or another..."18 Jelas bahwa kelompok teroris makin berkembang dan tidak lepas dari faktor organisasi yang baik dan kuat.

\section{Modus Operandi Terorisme}

Tindakan atau aksi teroris selalu disertai dengan maksud dan tujuan tertentu, apapun bentuk serangan yang dilakukan utamanya adalah untuk suatu tujuan. Lazimnya dalam satu gerakan teroris tidak mengharapkan dapat mencapai tujuan sebagai hasil langsung dari serangan, tetapi melalui akibat dan reaksi yang dilakukan dengan kejam dapat membangkitkan kepanikan dalam masyarakat dan pemerintah. secara keseluruhan efek teroris lebih kepada tekanan terhadap pemerintah karena pemerintah memiliki tanggung jawab dan mengerti berapa besar nilai yang akan dikeluarkan untuk dapat mencapai kondisi yang normal kembali. Teroris lebih menghendaki pemerintah menyerah dan mengakhiri kekejaman dengan menerima segala bentuk tuntutan teroris. Konsep ini merupakan dasar dari seluruh strategi teroris sekalipun setiap penyerangan memiliki perbedaan mendasar. ${ }^{19}$ Untuk mencapai seluruh maksud dan tujuan tersebut, teroris menggunakan beberapa cara, yaitu:

1. Menanamkan pengaruh yang kuat kepada pemerintah dan masyarakat tentang alasan mereka dan meyakinkan kepada masyarakat atas keinginan dan kemampuan untuk mencapai tujuan melalui pergerakan ini.

2. Membuat masyarakat mendukung alasan dan usaha mereka.

3. Membuat pemerintah tidak efektif dan menggantinya dengan kekuasaan mereka.

4. Menekan pemerintah untuk menggelar pasukan keamanan. ${ }^{20}$

Perkembangan teknologi yang semakin canggih zaman sekarang ini sangat menolong teroris untuk melaksanakan aksinya, perlengkapan yang sarat dengan teknologi mempermudah teroris melakukan penyerangan misalnya hanya dengan menekan remote control. Mode serangan langsung yang dilakukan teroris antara lain dengan menggunakan senjata api untuk membunuh, menculik, menyandera dan lain sebagainya sementara mode serangan tidak langsung adalah penggunaan perangkap yang tersembunyi seperti bom waktu, alat peledak atau model teknologi lain yang memiliki fungsi yang sama untuk membunuh. ${ }^{21}$ Selain itu menggunakan model yang menyerupai permainan yang didesain sedemikian rupa sehingga membuat orang terkecoh, tidak mengerti bahwa benda tersebut adalah alat yang dapat menyebabkan kehancuran yang luar biasa, peralatan tersebut dilengkapi dengan setting waktu untuk mengaktifkannya kemudian secara mekanis mesin itu akan bekerja sendiri sampai pada waktu yang telah ditentukan benda tersebut akan meledak seperti peristiwa yang terjadi beberapa waktu lalu yakni bahan/alat peledak (bom) yang dibuat dalam bentuk buku. $^{22}$ Hal ini menunjukkan bahwa teroris memiliki berbagai macam cara/metode/modus

${ }^{18}$ John Stott, Issues Facing Christians Today, (Grandrapids, Michigan: Zondervan Publishing House, 2006), 122.

${ }^{19}$ Adjie S, Terorisme...., 39.

${ }^{20}$ Ibid., 40.

${ }^{21}$ Ibid., 53.

${ }^{22}$ RCTI, Maret, 2011. 
dalam melaksanakan aksinya dan tentu dengan dukungan dari pihak yang lain. Dalam melakukan aksinya, teroris memiliki beberapa macam tipe penyerangan, antara lain:

1. Pembunuhan Terpilih: tindakan serangan terhadap sasaran yang dipilih/pembunuhan terhadap figur yang dikenal oleh masyarakat (pejabat, pendeta, ulama, dll). ${ }^{23}$

2. Pembunuhan Kelompok/sekelompok Orang: kebanyakan dilaksanakan dengan mempergunakan cara yang tidak langsung (membayar orang). Untuk sekelompok target tertentu, metode ini dapat digunakan dengan memberikan informasi kepada setiap anggotanya atau dengan orang yang mau bekerja sama dengan teroris dengan suatu imbalan tertentu. ${ }^{24}$

3. Perampokan/Pembunuhan demi Uang, Senjata dan Amunisi: hal ini dilakukan untuk memenuhi kebutuhan finansial, yang umum dilakukan adalah melakukan perampokan baik pada masyarakat umum maupun terhadap nasabah bank, kantorkantor pemerintah dan swasta pun menjadi incaran terutama pada hari-hari pembayaran gaji. Selain merampok juga mencuri barang-barang yang mudah dijual seperti emas dan lain sebagainya. Perolehan senjata, amunisi merupakan tujuan utama dari misi ini sekaligus yang disukai oleh teroris sekalipun dalam pelaksanaannya memerlukan perencanaan yang lebih mendalam dibanding serangan lainnya. $^{25}$

4. Serangan untuk Publikasi: tujuan dari serangan yang seporadis adalah utamanya untuk memperoleh publikasi dan pengakuan secara khusus, target yang dipilih adalah target yang dapat menciptakan pengakuan nasional dan internasional secara meluas dan mampu membuat pemerintah menderita dan terdesak untuk memenuhi tuntutan mereka, contoh dari tindakan ini adalah peristiwa penyanderaan menteri-menteri OPEC yang tengah mengadakan pertemuan di Wina pada tahun $1975 .^{26}$

5. Menciptakan Kerusuhan Massa: peristiwa yang melibatkan dua kelompok atau lebih, apabila sulit untuk menemukan kesepakatan, maka kelompok-kelompok ini sangat mudah memperoleh provokasi yang negatif, membakar emosi dan menjurus ke perilaku yang cenderung brutal dan kacau. Sebagaimana tindakan yang dilakukan oleh teroris Irish Republican Army (IRA) yang membunuh 11 orang dan melukai lebih dari 60 orang di Ulster bulan November 1987 dengan tujuan memprovokasi orang beragama Protestan untuk mengadakan pembalasan terhadap orang-orang yang beragama Katholik. ${ }^{27}$

Berdasarkan tipe/mode serangan yang digunakan, maka jelas bahwa teroris adalah kelompok yang sangat menyukai tindakan kekerasan atau anarkis dengan melakukan berbagai macam cara untuk mencapai tujuan sekalipun merugikan banyak pihak, dalam hal ini bukan hanya pemerintah tetapi juga masyarakat. Dalam menjalankan serangan, teroris tidak hanya mempersiapkan cara, modus, tipe dalam penyerangan tetapi juga taktik dan kelompok teroris

\footnotetext{
${ }^{23}$ Adjie S, Terorisme, 54.

${ }^{24}$ Ibid., 57.

${ }^{25}$ Ibid., 57-58.

${ }^{26}$ Ibid., 58, 60 .

${ }^{27}$ Ibid., 60-61.
} 
dikenal memiliki beraneka ragam pilihan taktik, di antaranya: serangan bom, pembakaran dan pembunuhan.

Berbagai macam cara atau taktik yang dilakukan oleh kelompok teroris nampak dalam beberapa peristiwa yang terjadi di Indonesia, misalnya bom yang diledakkan di depan Kedutaan Besar (Kedubes) Australia pada tanggal 9 September 2004 sekaligus merupakan teror bom ke-10 di Indonesia selama tahun $2004 .{ }^{28}$ Demikian halnya peristiwa yang terjadi di Situbondo pada Oktober 1996 yakni penyerbuan/pengrusakan gereja dan persekutuan Kristen baik Protestan, Pentakosa Katholik,Klenteng serta pembakaran gedung Pengadilan Negeri, pengrusakan toko-toko termasuk sekolah Kristen dan sekolah dan Panti Asuhan Katholik $^{29}$ merupakan tipe penyerangan yang menciptakan kerusuhan massa dan ini adalah bagian dari aksi yang dilakukan oleh kelompok teroris.

\section{Profil Kelompok Terorisme}

Profil kelompok terorisme dibagi dalam dua bagian yakni nasional dan internasional. Profil, organisasi ataupun jaringan kelompok teroris nasional merupakan bentuk jaringan yang beroperasi di dalam negaranya sendiri ataupun di wilayah tertentu, hal ini dimungkinkan karena adanya keterbatasan dana, sponsor dan kepentingan. Sedangkan profil, jaringan atau organisasi teroris international beroperasi tanpa terikat oleh batas wilayah suatu negara ataupun benua. Contoh profil kelompok teroris internasional adalah Abu Nidal Organization (ANO) dengan nama lain Fatah-the Revolutionary Council (FRC) atau Revolutionary Organization of Socialist Muslim (RSOM) yang dibentuk tahun 1974, bermarkas besar di Libya dengan anggota kurang lebih 500 orang. Tujuan politik atau target dari kelompok ini antara lain: melakukan pemberontakan bersenjata melawan musuh Zionist, adalah prioritas utama dalam perlawanan pergerakan Palestina. Usaha menggagalkan negosiasi perdamaian Palestina-Israel, dengan melakukan teror kepada pro-Arafat Palestina dan menyerang target di Eropa dan Timur Tengah. ${ }^{30}$

Profil kelompok teroris nasional adalah Jemaah Islamiyah (JI), merupakan kelompok jaringan teroris di Asia Tenggara yang juga memiliki kaitan erat dengan Al-Qaeda. Jaringan ini terbentuk di tahun 1990-an menyusul sebuah keinginan untuk membentuk dan perlunya menciptakan ideologi negara-negara Islam yangg terdiri dari Indonesia, Malaysia, Singapura, kawasan Philipinna Selatan dan Thailand Selatan. Jemaah Islamiyah (JI) bertanggung jawab atas peledakan bom di Bali tanggal 12 Oktober 2002 yang menewaskan 200 orang dan mencederai 300 lainnya. Perencanaan aksi Bali merupakan hasil pertemuan anggota JI di Thailand termasuk penyerangan terhadap soft target, kawasan wisatawan di Singapura namun pemerintah Singapura berhasil mengungkap perencanaan tersebut pada Desember 2001 sehingga aksi tersebut dibatalkan. Jumlah anggota Jemaah Islamiyah (JI) tidak diketahui dengan pasti karena menyebar di seluruh kawasan Asia Tenggara. Adapun daerah operasi Jemaah Islamiyah (JI) adalah Indonesia, Malaysia, Singapura, Philipinna

${ }^{28}$ Petrus Octavianus, Menuju Indonesia Jaya (2005-2030) \& Indonesia Adidaya (2030-2055) Jilid II, (Jakarta: Bahtera Grafika, 2005), 182.

${ }^{29}$ Herlianto, Gereja di Tengah Gejolak, 87.

${ }^{30}$ Adjie S, Terorisme, 98. 
Selatan dan Thailand Selatan, JI juga mendapatkan bantuan dari negara-negara Islam Timur Tengah, Asia Selatan, LSM dan Al-Qaeda. ${ }^{31}$

Sehubungan dengan hal ini, di Indonesia sendiri terdapat beberapa organisasi Islam revivalis yang sering disebut "Gerakan Islam Baru" (new Islamic movement) yang pemikirannya berasal dari berbagai organisasi gerakan Islam di Timur Tengah misalnya Hizbut Tahrir Indonesia (HTI) yang merupakan cabang resmi dari Hizbut Tahrir Internasional yang berpusat di Yordania. Sedangkan Dakwah Salafi termasuk Lasykar Jihad adalah himpunan dari para aktivis dakwah Salafi yang berjejaring dengan gerakan Salafi di Timur Tengah khususnya Arab Saudi dan Kuwait. Nasir Abas, salah seorang mantan anggota Jama'ah Islamiyah (JI) menyatakan bahwa tokoh MMI (Majelis Mujahidin Indonesia), Abu Bakar Baasyir dan Abdullah Sungkar merupakan pemimpin JI yang memiliki hubungan langsung dengan salah satu faksi mujahiddin Afganistan, yakni Abdurrasul Sayyaf.

Dalam perkembangan selanjutnya jaringan Jama'ah Islamiyah (JI) kemudian berkembang menjadi jaringan teroris di Indonesia dan memiliki kontak dengan sukarelawan Arab di Afganistan. Organisasi inipun memiliki keterkaitan dengan jaringan Jama'ah Islamiyah (JI) di Asia Tenggara dan memiliki kontak dengan Osama Bin Laden dan Aiman At-Tawakhiri (pemimpin Jama'ah al-Muslimin Mesir yang bergabung ke Al-Qaidah). ${ }^{32}$ Dengan demikian jelas bahwa berbagai peristiwa kekerasan yang terjadi di Indonesia beberapa waktu ini baik berupa peledakan bom termasuk bom bunuh diri, pengrusakan bangunan ibadah, kerusuhan yang berbau SARA dan tindakan lainnya adalah merupakan bagian dari serangan terorisme tanpa menyudutkan satu agama/keyakinan tertentu dan sekalipun ada banyak pihak yang sulit mengakui hal tersebut. Berbagai peristiwa tersebut menunjukkan dengan jelas adanya suatu maksud dan tujuan dari kelompok teroris dan mencapai maksud dan tujuan tersebut dengan menggunakan banyak cara sekalipun merugikan dan mencelakakan banyak orang.

\section{PEMBAHASAN}

\section{Tanggapan Etika Kristen Terhadap Terorisme}

Keberanian teroris dalam melakukan tindakan-tindakan kekerasan/anarkis hingga pembunuhan, bahkan bunuh diri dengan menggunakan berbagai cara menunjukkan suatu keberanian yang luar biasa diiringi dengan motivasi yang kuat yang ada di balik tindakan tersebut. Hal ini disebabkan oleh karena faham yang sangat kokoh sehingga berani bertindak sekalipun itu menghilangkan nyawa banyak orang bahkan nyawa sendiri. Demikian halnya dengan berbagai peristiwa di Indonesia yang seringkali dihubungkan dengan SARA tidak dapat dipisahkan dari kehidupan orang Kristen yang justru menjadi sasaran dari berbagai peristiwa yang terjadi.

Menyikapi hal ini, orang Kristen sebaiknya tetap menunjukkan sikap yang baik dan bersahabat, tidak terpancing dengan situasi yang ada sebagaimana yang Tuhan Yesus ajarkan kepada para murid bahwa ada faham yang dimiliki seseorang beragama dan dengan

\footnotetext{
${ }^{31}$ Ibid., 275-276.

${ }^{32}$ M. Imdadun Rahmat, Ideologi Politik PKS, (Yogyakarta: LKiS, 2008), 77.
} 
fahamnya ia melakukan hal-hal yang sangat bertentangan dengan kebenaran agama itu sendiri. Tuhan Yesus memberitahukan dan menekankan berulang kali bahwa ada orang yang akan membunuh umat Tuhan dan mereka merasa melakukan perintah Allah. Ini merupakan suatu faham yang luar biasa kuatnya sehingga tidak segan-sengan untuk membunuh orang lain dan mengorbankan dirinya sendiri. ${ }^{33}$ Faham seperti ini yang banyak dimiliki oleh kelompok teroris, yang bergerak bukan hanya demi uang tapi juga berdasarkan kepercayaan atau keyakinannya.

Apapun situasi dan kondisi yang dialami oleh orang Kristen, dari sisi etika Kristen itu bukanlah alasan untuk melakukan tindakan anarkis sebagai bentuk pembalasan, tidak dapat disangkal bahwa Alkitab jauh sebelumnya telah mengajarkan hukum kasih yang tidak dapat ditawar-tawar hingga Tuhan Yesus sendiri menyerahkan diri-Nya untuk disalibkan karena kasih-Nya kepada manusia yang berdosa. Orang Kristen dituntut bukan hanya menerima dan merasakan kasih tetapi bagaimana membagikan kasih itu kepada orang lain. Di sisi lain Tuhan Yesus menghendaki agar orang Kristen menjadi garam dan terang kapan pun dan di mana pun serta terhadap siapapun (Mat. 5:13-16). Dengan tetap mengingat bahwa kebaikan adalah apa yang dikehendaki Allah, Allah menjadi tolok ukur dan bukan manusia karena dalam etika Kristen, kehendak Allah adalah mutlak, wajib dan tidak dapat ditawar-tawar.

\section{Kesimpulan}

Orang Kristen sebaiknya tetap bersikap bijaksana dalam menyikapi masalah-masalah yang berhubungan dengan teroris dan terorisme yang ada di Indonesia, bersikap waspada dan bijaksana terhadap segala macam berita, ajaran, rumor, isu-isu kosong dan teror sehingga tidak mudah untuk diprovokasi oleh orang/pihak-pihak yang tidak bertanggung jawab. Orang Kristen tetap berhati-hati dalam bertingkah laku dan perlu untuk mengantisipasi segala kemungkinan agar dapat mempersiapkan diri menghadapinya. Selain itu orang Kristen sebaiknya membawa mandat sosial, budaya, politik, ekonomi dan agama dalam kehidupan bermasyarakat serta membangun relasi yang baik dengan sesama.

Di samping itu hal penting yang sebaiknya dimengeri dan dipahami oleh orang Kristen adalah menyadari bahwa musuh terorisme bukanlah darah dan daging, tetapi sebaliknya telah dikendalikan oleh kuasa kegelapan. Di balik teror ada tipu muslihat iblis yang luar biasa itu sebabnya tindakan kekerasan dalam menghadapi terorisme tidak menjamin adanya penyelesaian masalah, namun tindakan yang sesuai dengan hukum dan keadilan tetap dipertahankan dan dilaksanakan tanpa kompromi (Ef. 6:11b). Dan itu berarti bahwa gereja sebagai wadah persekutuan/komunikasi orang Kristen pun memiliki tanggung jawab yang sama untuk tetap menjadi garam dan terang bagi banyak orang. Gereja tetap setia kepada kebenaran dan misi-Nya untuk memberitakan Injil sekalipun menghadapi situasi yang tidak mudah karena gereja memiliki kebenaran Firman Allah yang hidup yang dapat bertahan menghadapi segala kemungkinan.

\footnotetext{
${ }^{33}$ Halim, Terror, Terroris dan Terorisme, 56.
} 


\section{REFERENSI}

Departemen Pendidikan dan Kebudayaan. Kamus Besar Bahasa Indonesia, Jakarta: Balai Pustaka, 1988

Halim, Makmur, Terror, Terroris dan Terrorisme, Suatu Perspektif Kristen, James Steven: Shalom Publishers.

Herlianto. Gereja di Tengah Gejolak Kota-kota, Bandung: YABINA, 1997.

Octavianus, Petrus. Menuju Indonesia Jaya (2005-2030) \& Indonesia Adidaya (2030-2055) Jilid II, Jakarta: Bahtera Grafika. 2005

Rahmat, M. Imdadun. Ideologi Politik PKS, Yogyakarta: LkiS, 2008

S, Adjie. Terorisme, Jakarta: Pustaka Sinar Harapan, 2005

Salim, Peter \& Yenny. Kamus Bahasa Indonesia Kontemporer, Jakarta: Modern English Press., 1991.

Stott, John. Issues Facing Christians Today, Grandrapids, Michigan: Zondervan Publishing House, 2006. 